\title{
HERMENEUTIKA FENOMENOLOGIS PAUL RICOEUR
}

\author{
Gustaf R. Rame \\ qui president a une exegese, c'est-a-dire a L'interpretation \\ d'untexte singulier ou d'un ensemble de signes usceptible \\ d'etre considere comne un text"1
}

\section{PENDAHULUAN}

Paul Ricoeur adalah salah satu nama terkenal dalam kancah filsafat. Ia dikenal tajam dalam pemikiran fenomenologis yang membedah makna dalam narasi teks menjadi terang bagi pencari kebenaran otentik. Cakrawala pemikirannya melingkupi hampir semua topik filsafat kontemporer, sehingga ia dinobatkan sebagai pemenang hadiah Balzan Price for Philosophy pada tahun $1999 .^{2}$ Tidak heran kemudian apabila ia termasuk tokoh yang masih hidup yang banyak diperb“...Nous Etendrons toujours par hermeneutique La theorie de regle incangkan dengan panjang lebar. Berbagai kajian tentang Ricoeur diselenggarakan di berbagai tempat, baik secara personal insidentil oleh para pemikir dan penulis maupun secara kolektif sistematis oleh lembaga-lembaga perguruan tinggi. ${ }^{3}$

Lebih khusus lagi dalam wilayah studi hermeneutika, Ricoeur telah menyumbangkan, bukan hanya gagasan-gagasan (ideas) baru tetapi bahkan

1 Yang kita maksud dengan hermenutika adalah sebuah teori yang mengatur tentang metode penafsiran, yaitu interpretasi terhadap teks, serta tanda-tanda lain yang dapat dianggap sebagai sebuah teks. Dikutip dari Richard Palmer, Hermenutics, Interpretation Theory in Schleirmacher, Dilthey, Heidegger, and Gadamer (Northwestern University Press, 1969), 43, footnote no.23

${ }^{2}$ Menurut ungkapan lembaga itu, Ricouer terpilih karena: “...his capability in bringing together all the most important themes and indications of $20^{\text {th }}$ century philosophy and realaborating them into an original synthesis whinch turn language in particular, that which is poetic and metaphoric into a chosen place revealing a reality that we cannot manipulate, but interpret in diverse ways, and yet all coherent..." International Balzan Foundation 1999, "Paul Ricouer Laudatio and Profile" pada http: //www.balzan.it/english/pb1999/ricoeur/laudatiopprofolio.html

3 Lih. mis. "Graduate Hermeneutic Spring" di http//www.uta.edu/philosophy/ faculty/reader/GrHermSy/Samp.html; atau Paul Ricouer Reading Group” di http//tcs.ntu. ac.uk.k.research/ricouer.html 
wawasan (insight) baru. ${ }^{4}$ Kekhasan kajian hermeneutika Ricoeur, bukan hanya karena ia adalah pemikir mutakhir sehingga memiliki kesempatan untuk meng-up-date pemikiran-pemikiran sebelumnya, melainkan ia juga meng-up-grade dengan menampilkan corak kajian hermeneutika yang sepenuhnya berbeda dengan kajian-kajian yang ada.

Sebagaimana yang dikatakan Joseph Bleicher dalam Contemporary Hermeneutics $(1981)^{5}$ yang menempatkan pemikiran Ricoeur di luar tiga tradisi pemikiran hermeneutik: hermeneutika metodologis, hermeneutika filosofis dan hermeneutika kritis. Ini menunjukkan bahwa corak pemikiran Ricoeur tidak dapat dimasukkan dalam salah satu dari tiga tradisi itu. Dan dengan melihat pada para komentator Ricoeur seperti Don Ihde $^{6}$ dan Patrick L. Bourgouis, ${ }^{7}$ Zainal Abidin ${ }^{8}$ bahkan berani melangkah lebih jauh dengan mengatakan bahwa untuk mengkaji hermeneutika Ricoeur, tidak perlu melacak akarnya pada perkembangan hermeneutika sebelumnya. ${ }^{9}$

\section{RICOEUR DAN HERMENEUTICAL DESPUTE}

Sebelum melangkah pada kajian pemikiran Ricoeur, ada baiknya kita melihat kontur yang lebih luas dari posisi pemikiran Ricoeur sendiri dalam peta pemikiran hermeneutika. Hal ini akan dapat memudahkan kita untuk memahami pengaruh dan tantangan dari pemikirannya. Sebab, dalam genealogi intelektual, setiap pemikiran selalu merupakan aksi sekaligus reaksi terhadap wacana yang sudah ada.

Mengikuti penjelasan Bleicher, ${ }^{10}$ pemikiran Ricoeur dapat dianggap menjembatani perdebatan sengit dalam peta hermeneutika antara tradisi

\footnotetext{
${ }^{4}$ Untuk bibliografi karya oleh maupun tentang Ricoeur yang mencapai puluhan judul, lihat "References on Hermeneutics."

${ }^{5}$ Bleicher sendiri menempatkan Ricoeur sebagai penghubung sekaligus pembeda dari aliran-aliran hermeneutika yang ada. Bahkan ia juga dianggap sebagai penghubung antara dua tradisi filsafat besar yaitu fenomenologi Jerman dan strukturalisme Perancis Press, 1971).

${ }^{6}$ Don Idhe, Hermeneutics Phenomenology (Evanston: Northwestern University

${ }^{7}$ Patrick L. Bourgouis, Extenssion of Ricoeur Hermeneutics (The Hague: Matinus Njhoff, 1975).

${ }^{8}$ Lih. Zainal Abidin, "Fenomenologi" Hermeneutik Paul Ricoeur, Skripsi UGM 1990, 144-145.

9 Sikap inipun sebenarnya juga diambil oleh Richard Palmer dengan menempatkan posisi Ricoeur yang sepenuhnya terpisah dari tokoh-tokoh hermenutik yang dibahasnya; Lih. Palmer, Hermenutics, Interpretation Theory..., 43-45.

10 Joseph Bleicher, Contemporary Hermeneutics, Hermeneutics and Method, Philosophy, and Critique (London: Ruthledge \& Kegan Paul, 1980), Chapter 13, 233-235.
} 
metodologis dan tradisi filosofis yang masing-masing diwakili oleh Emilio Betti dan Hans-George Gadamer. ${ }^{11}$ Di satu sisi Ricoeur berpijak pada titik berangkat yang sama dengan Betti bahwa hermeneutika adalah kajian untuk menyingkapkan makna objektif dari teks-teks yang memiliki jarak ruang dan waktu dari pembaca, ${ }^{12}$ namun di sisi lain, ia juga menganggap bahwa seiring perjalanan waktu niat awal dari penulis sudah tidak lagi digunakan sebagai acuan utama dalam memahami teks. Dan ini adalah posisi Gadamer. $^{13}$

Lebih jauh lagi, Ricoeur juga dianggap menjadi mediator dari posisi tradisi hermeneutika romantic dari Schleirmacher dan Dilthey dengan hermeneutika filosofisnya Martin Heidegger. ${ }^{14}$ Mengikuti Dilthey, Ricoeur menempatkan hermeneutika sebagai kajian sebagai ekspresi-ekspresi kehidupan yang terbakukan dalam bahasa (linguistically fixed expression of life $){ }^{15}$ namun ia tidak berhenti pada langkah psikologisme untuk merekonstruksi pengalaman penulis (seperti Schleirmacher) ${ }^{16}$ maupun usaha penemuan diri sendiri pada orang lain (seperti Dilthey) ${ }^{17}$ melainkan untuk menyingkapkan potensi keber-Ada-an atau Eksistensi (seperti Heidegger). ${ }^{18}$

Bahkan Ricoeur dapat ditempatkan sebagai perpaduan antara dua tradisi filsafat besar, yaitu fenomenologi Jerman $^{19}$ dan Strukturalisme Perancis. ${ }^{20}$ Dari arah fenomenologi, Ricoeur juga memadukan antara

${ }^{11}$ Bleicher, Contemporary Hermeneutics..., Chapter 13, 233-235.

12 Ricoeur, "The Tast of Hermeneutics," dalam Hermeneutics and Human Sciences, trans.\& ed. John B. Tomphson (Canbridge: Canbridege University Press, t.t), 48.

${ }^{13}$ Ibid., 59 dst.

${ }^{14}$ Ricoeur sendiri menganggap pemikiran Heidegger sebagai sambutan langsung terhadap persoalan yang tak terjawab oleh Dilthey; Lih. Ricoeur, Ibid, 53-54.

15 Dilthey memiliki rumusan Interpretation-Expression-Understanding; Lih. Palmer, Hermenutics, Interpretation Theory in Schleirmacher, Dilthey, Heidegger, and Gadamer, 107-115.

${ }^{16}$ Schleimacher menganggap bahwa rekonstruksi psikologis merupakan langkah utama dan puncak dari metode hermeneutika untuk memahami teks; Lih. Palmer, Ibid., 86.

${ }^{17}$ Sedangkan bagi Dilthey, usaha pemahaman diri dapat dilakukan dengan melalui pemahaman terhadap orang lain. Palmer, Ibid., 14-15.

${ }^{18}$ Ibid., 130.

${ }^{19}$ Ricoeur termasuk perintis kajian Husserlian di Prancis, karena ia yang pertama kali menerjemahkan karya Husserl ke dalam bahasa Prancis; Lih. John B Thompson, "Editors Introduction" dalam Paul Ricoeur, Hermeneutic and Human Science, 2.

${ }^{20}$ Strukturalisme adalah aliran filsafat bahasa modern yang berkembang di bawah pengaruh Ferdinand de Saussure, yang kemudian dikenal dengan Simiologi; Lih. William McNeil \& Karen S. Feldman, Continental Philosophy (Massachusset: Blackwell Pub., 1998), 297. 
tendensi metafisik Cartesian Edmund Husserl dan tendensi eksistensial dari Heidegger, ${ }^{21}$ sedangkan dari Strukturalisme ia mengadopsi baik dari aliran linguistik dari Ferdinand de Saussure maupun aliran Antropologis dari Claude Levi-Strauss. ${ }^{22}$ Sebagai tambahan, Ricoeur juga mengakomodir tendensi kritik ideologi di satu sisi dan psikoanalisis di sisi lain untuk melakukan eksplorasi isi pada kajian hermeneutika yang ia lakukan. ${ }^{23}$

\section{MENCANGKOK ${ }^{24}$ HERMENUTIKA DARI FENOMENOLOGI}

Selanjutnya mari kita menukik lebih dalam pada penelusuran pemikiran hermeneutika menurut Paul Ricoeur. Sebagaimana dikatakan di atas, meskipun mengakomodir semua tendensi dalam sejarah hermeneutika, bahkan di antara berbagai cabang dan model hermeneutika yang saling bersaing, namun Ricoeur sekaligus membuka wawasan baru dalam kajian hermeneutika yang sekaligus mengatasi atau melampaui carut-marut hermeneutical despute yang sudah berlangsung dan bukan sekedar mendamaikan semata. Dalam hal ini barangkali akan cukup memadai bagi kita untuk memfokuskan pada dua tema sentral dalam pemikiran hermeneutika Paul Ricoeur, yaitu apa yang ia sebut sebagai jalan panjang hermeneutika dan setelah itu kita akan menelaah apa yang menurutnya problem sentral dalam hermeneutika: yaitu hubungan antara bahasa lisan dan metafor di satu sisi dengan bahasa tulis dan teks di sisi lain. Dengan menelaah dua tema itu, barangkali kita sudah akan dapat mengikuti proyek

${ }^{21}$ Paul Ricouer, "Existence and Hermeneutics", dalam Bleicher, Contemporary Hermeneutics..., 240-241.

${ }^{22}$ Ibid., 22-24.

${ }^{23}$ Pada aspek ini sepertinya tidak langsung, tapi justru sentral. Sebagaimana yang nantinya dapat dilihat bagaimana Ricoeur memainkan Psikoanalisis dalam mengembangkan hermeneutika fenomenologis dan di tempat lain juga dapat disaksikan bagaimana Ricouer menggunakan kritik ideologi untuk membangun hermeneutics suspicion; Lih. Ricouer, "Hermeneutics and Critics of Ideology," dalam Hermeneutic and Human Science.

${ }^{24}$ Istilah mencangkok (grafting, greffer) digunakan oleh Ricoeur sendiri untuk menandai usahanya memadukan antara hermeneutika ilmu (metodologi) dengan fenomenologi sebagai filsafat (ontology). Tujuan Ricouer adalah mengembangakan sebuah hermeneutika yang metodologis sekaligus ontologism. Dari sini orang kadang-kadang bingung untuk menata kedua kata tersebut, mana yang subjek dan mana yang predikat. Misalnya, Zainal Abidin menulis Skripsi berjudul "Fenomenologi Hermeneutik Paul Ricouer," UGM, 1992. 
utama Ricoeur, yaitu mencangkokkan Hermenutika dengan fenomenologi. ${ }^{25}$

Ricoeur menganggap bahwa persoalan hermeneutika adalah persoalan yang sudah sangat panjang sejarahnya, ${ }^{26}$ mulai dari tradisi Yunani hingga pemikiran teologi abad pertengahan. Ini disebutnya sebagai fase pertama hermeneutika klasik. Di sini hermeneutika sudah menghadapi persoalan filosofis, di mana ia tidak hanya merupakan sebuah keahlian teknis dalam menafsirkan teks tertentu (techne hermeneutikhe) melainkan juga berhadapan dengan persoalan tentang pemahaman dalam arti yang lebih luas. Inilah yang diangkat dalam pemikiran Aristoteles dalam Peri Hermeneia. Pada tahap ini sudah dihasilkan dua arah kajian hermeneutika, yaitu sebagai interpretasi atau tafsir terhadap suatu teks tertentu serta sebagai pemahaman terhadap konsep pemahaman itu sendiri. ${ }^{27}$

Sedangkan fase kedua perkembangan hermeneutika klasik dibidangi oleh Schleirmacher ${ }^{28}$ dan terutama Dilthey. ${ }^{29}$ Pemikir yang terakhir ini menurut Ricoeur telah berjasa untuk membangkitkan pertanyaan fundamental mengenai keunikan posisi manusia vis-à-vis objek alami, sehingga kajian terhadap manusia qua manusia harus menggunakan metodologi yang berbeda dengan ilmu alam. Dilthey mengusulkan sebuah ilmu kemanusiaan (Geistesswissenschaften) yang secara epistemologi akan bersaing dengan ilmu-ilmu alam yang positivistik. ${ }^{30}$ Pertanyaan kedua dari Dilthey yang fundamental adalah kesadaran historis. Bahwa manusia adalah wujud historis yang hanya dapat hidup, dipahami, dan memahami secara historis. Kehidupan selalu dalam konteks. Kebenaran bagi manusia selalu dalam konteks. ${ }^{31}$ Namun, Ricoeur mencatat bahwa pertanyaan yang diajukan Dilthey ini menyimpan residu problem yang tak mampu ia reduksi sendiri: sebagai mahluk historis bagaimana manusia dapat memahami sejarah secara historis? Bagaimana kehidupan dapat menampilkan diri

${ }^{25}$ Sebenarnya berbagai cabang kajian yang dikembangkan Ricoeur, mulai dari hermeneutika, ontologi, teologi, ideologi, etika, hingga pendidikan, menyusun sebuah bangunan besar yang padu di mana ujungnya saling bertemu. Bila kita memasuki sebuah kajian kita akan menembus ke dalam kajian-kajian yang lain.

${ }^{26}$ Jean Groundin dalam Introduction to Philosophical Hermeneutics (New Haven: Yale University Press, 1994), mengurutkan tahapan ini dari zaman Yunani, Abad pertengahan, Pencerahan, hingga modern.

${ }^{27}$ Ricouer, Existence and ..., 236-238.

${ }^{28}$ Palmer, Hermenutics, Interpretation Theory..., 84.

${ }^{29}$ Ricoeur, The History of..., 49.

${ }^{30}$ Meskipun ia tampaknya masih terkurung dalam sangkar yang justru ingin ia tolak

\footnotetext{
${ }^{31}$ Palmer, Hermenutics, Interpretation Theory..., 103-106.
} 
sekaligus menyingkapkan makna dirinya yang dapat terpahami oleh wujud historis lain $?^{32}$

Persoalan inilah yang menurut Ricoeur memicu pertanyaan tentang ontology of understanding. ${ }^{33}$ Yaitu untuk menjawab pertanyaan paradox di atas maka kita harus lebih dulu mengetahui hakikat manusia sebagai keberada-an yang historis, keberadaan yang terjebak dalam arus waktu, Das Sein, Being and Time. $^{34}$ Hermeneutika bukan lagi diarahkan kepada teks melainkan kepada realitas itu sendiri untuk menemukan eksistensi keberada-an yang bersifat historis. Namun jalan ini oleh Ricoeur dianggap sebagai potong kompas karena melakukan lompatan dari hermeneutika pada level metode kepada level metafisika atau ontology. ${ }^{35}$ Dan ini yang dilanjutkan oleh Gadamer dengan memisahkan metode dan kebenaran (truth and metode). Sehingga pertanyaan yang muncul adalah, dalam pemahaman jenis apakah yang ada di situ? $?^{36}$

Sedangkan menurut Ricoeur, pertanyaan yang tepat mestinya adalah: dalam kondisi bagaimana sebuah wujud yang mengetahui dapat memahami teks atau sejarah? ${ }^{37}$ Pertanyaan ini lebih memadai karena lebih sistematis dalam usaha mengarahkan hermeneutika dari level metode menuju metafisika. Sedangkan pertanyaan terdahulu mengalami lompatan sehingga antara metodologi dan ontology tetap terdapat jarak yang tak terjembatani. ${ }^{38}$

Selanjutnnya, Ricoeur menguraikan bahwa proses okulasi antara metode dengan metafisika dari teori ke ontologi, dari hermeneutika ke fenomenologi, terdapat tiga tahapan yang harus dilalui. ${ }^{39}$ Pertama adalah level semantic, yaitu bahwa bahasa merupakan wahana utama bagi ekspresi

${ }^{32}$ Ricoeur, The Task of..., 53.

${ }^{33}$ Ricoeur, Existence and Hermeneutics..., 238.

${ }^{34}$ Heidegger menulis Being and Time dalam rangka memetakan bahwa Being adalah implicit dalam Time. Sebenarnya Heidegger ingin melanjutkan dengan melakukan pembalikan (Kehre) tentang Time dan Being, tapi gagasannya macet karena menurutnya bahasa metafisika tidak memadai untuk itu. K. Bertens, Filsafat Barat Abad XX, InggrisJerman (Jakarta: Gramedia, 1990), 150-51.

${ }^{35}$ Ricoeur, Existence and Hermeneutics..., 239.

${ }^{36}$ Ibid.

37 "On what condition being that knowing understand text or history?" Sementara rumusan pertanyaan sebelumnya adalah: "What kind of being whose being consist in interpretation? Ricoeur, Existence and Hermeneutics..., 239.

38 Ibid., 340.

39 Tahapan ini dinamakan sebagai jalan panjang yang dilawankan dengan lompatan ontologisnya Heidegger dan Gadamer. Namun ini juga mengimplikasikan ketidaklangsungan (indirectness) dan fenomenology of being; Ibid., 266. 
ontologi. ${ }^{40}$ Oleh karena itu, poros yang tidak dapat ditinggalkan adalah kajian terhadap struktur bahasa dan kebahasaan mencakup keseluruhan sistem symbol sebagai hakikat dari berbahasa. Keberbahasaan ini dalam tataran normal akan tercakup dalam kajian simbolisme sebagai kajian terhadap sistem bahasa. ${ }^{41}$ Sedangkan dalam tataran abnormal menjadi kajian dari psikoanalisis, yaitu dalam usaha untuk mengungkapkan makna yang tak terbahasakan karena terepresi atau pengungkapan makna yang terdeviasi atau bahkan tereduksi, karena kendala dalam sistem komunikasi. ${ }^{42}$

Level semantic ini memiliki peran fundamental dalam menjaga hubungan antara hermeneutika dengan metode di satu sisi dan ontology di sisi yang lain. ${ }^{43}$ Hermeneutika sebagai metode, sebagai praktik yang dijalankan, akan menjaganya terhindar dari langkah untuk memisahkan konsep metode dan konsep kebenaran. Selanjutnya, ia juga bermanfaat dalam hubungan dengan fenomenologi sebagai usaha untuk menangkap realitas "keber-ada-an" manusia bukan sebagai entitas objektif dan statis melainkan equivocal dan intensional. ${ }^{44}$ Dan terakhir, tataran penampang semantik ini akan menjaga pintu penghubung antara hermeneutika dengan filsafat bahasa yang lain dan bahkan filsafat secara keseluruhan. ${ }^{45}$

Tahap kedua adalah level refleksi, yaitu mengangkat lebih tinggi lagi posisi hermenutika pada level filosofis. ${ }^{46}$ Level semantic

\footnotetext{
${ }^{40}$ Sebenarnya ini juga merupakan jargon utama Gadamer, "Sein das verstanden widen kann, ist sprache" being that can be understood is language, Bertens, Filsafat Barat Abad..., 231.

${ }^{41}$ Ricoeur mendefenisikan simbolisme sebagai: “ . ...any structure of signification in which a direct, primary, literal meaning designates, in addition, another meaning which is indirect, secondary dan figurative and which can be apprehenden only through the first." Ricoeur, Ibid., 245.

42 Ricoeur menganggap bahwa jasa utama psikoanalisis adalah memecahkan persoalan distorsi makna baik karena represi maupun miskomunikasi. Dengan demikian mencegah terjadinya kesalahpahaman karena ungkapan-ungkapan makna yang tidak normal, melalui pengenalan terhadap posisi subjek dari situasi ketertekanannya; Ibid., 252254.

${ }^{43}$ Ibid., 247.

${ }^{44}$ Ricoeur, Existence and Hermeneutics..., 248.

${ }^{45}$ Ricoeur secara luas menggunakan kajian filsafat bahasa dalam hermeneutiknya. Rujukan intensif ia lakukan pada Wittgenstein, I.A. Richard, Max Black maupun Moore Berdsley; Lih. Ricoeur "Metaphor and Central Problems of Hermeneutics," dalam Hermeneutics and Human Sciences, 170.

${ }^{46}$ Ricoeur menganggap bahwa dengan berada pada level semantic hermeneutika belum menempati posisi sebagai sebuah filsafat. Sebab filsafat menurutnya adalah bagaimana mempertanyakan realitas dalam konteks general, Yvanka B. Raynova,
} 
memungkinkan hermeneutika memijakkan kakinya pada tingkap teknik aplikatif kebahasaan. Sedangkan pada level ini hermeneutika harus melewati tahap yang lebih tinggi untuk memperoleh posisi sebagai sebuah filsafat. Posisi itu akan teraih dengan melalui proses ulang-balik antara pemahaman teks dengan pemahaman diri. ${ }^{47}$ Proses ini berlangsung mirip dengan lingkaran hermeneutic Schleirmacher, ${ }^{48}$ di mana yang satu menghasilkan yang lain dan keduanya harus dilaksanakan secara bersama. Tujuan hermeneutika dalam hal ini adalah memahami diri sendiri melalui pemahaman orang lain. Yaitu dengan mengatasi jarak waktu yang memisahkan antara kita dengan teks. Namun refleksi ini tidak terjadi dalam pola Cogito Cartesian ${ }^{49}$ di mana entitas diri adalah sesuatu yang statis dan objektif terkungkung dalam hubungan subjek-objek, melainkan dalam sebuah benturan langsung dalam realitas sebagaimana yang diistilahkan Dilthey dengan ekspresi kehidupan. ${ }^{50}$ Dalam hal ini yang kita gunakan bukan logika positivistic yang bisa dijungkirbalikkan, melainkan logika transcendental yang berpijak pada perjumpaan langsung dengan realitas. ${ }^{51}$

Tahap ketiga adalah level eksistensial. ${ }^{52}$ Pada tahap ini, menurut Ricoeur hermeneutika memasuki tahap paling kompleks yaitu ontology membeberkan hakikat dari pemahaman, ontology of understanding melalui methodology of interpretation. Pada tahap ini akan tersingkap pemahaman dan makna, bagi manusia, ternyata berakar pada dorongan-dorongan yang

\footnotetext{
"Philosphie et Theologie: les deux voies de Paul Ricouer," Labirint, vol. 2 Winter 2000, http://h2hobel.phl.univie.ac.at/'iaf/Labyrinth/2000/raynova2.html., 2-3. Di tempat lain, pada konferensi filsafat entretien avec Pul Ricoeur", http://h2hobel. Phl. Univie. ac.at/'iaf/Labyrinth/2000/ricouer.html

${ }^{47}$ Sekali lagi di sini kita menyaksikan jejak-jejak Dilthey.

${ }^{48}$ Palmer, Hermenutics, Interpretation Theory..., 87.

${ }^{49}$ Cogito di sini adalah diri yang berpikir secara objektif.

${ }^{50}$ Lih. Palmer, Ibid., 111 dst.

${ }^{51}$ Maksudnya, adalah bahwa selama argument itu dibangun dengan logika, tidak peduli berbagai bukti yang diajukan, maka ia dengan sangat mudah akan dijungkirkan dengan logika pula. Seperti misalnya yang dilakukan oleh Bertrand Russel dalam Why I am not a Christian, di mana ia membalikkan semua argumentasi tentang adanya Tuhan. Dan dengan logika yang sama pula ia berkesimpulan bahwa Tuhan tidak mungkin ada. Ricouer mengatasinya sama dengan Dilthey, yaitu masuk ke dalam tahap sebelum terjadinya dikotomi subjek-objek dalam pengetahaun.

52 Eksistensialisme Ricouer ini lebih dekat kepada Jaspers, Marcel dan MarleuPonty ketimbang kepada Sartre. Yaitu eksistensi dalam batas-batas kontek historis. Sementara Sartre menjadikan eksistensi sebagai keterbatasan manusia.
} 
lebih mendasar yang bersifat instingtif: hasrat. ${ }^{53}$ Dari hasrat inilah lahir kehidupan, dan selanjutnya bahasa. Untuk menyingkapkan realitas hasrat ini, sebagai realitas yang tidak disadari instingtif, Ricoeur mengajak kita melewati lorong Psikoanalisis. ${ }^{54}$ Melalui lorong ini kita diajak untuk menemukan the archeology of subject $t^{55}$ - suatu sumber data diri paling primitif dan mentah. Dari sini kita akan menyadari, kata Ricoeur, bahwa ontology pemahaman itu bisa ditarik kepada arah awal dan ke dalam. ${ }^{56} \mathrm{Di}$ samping itu, ontology pemahaman manusia juga memiliki akar pada kesadarannya terhadap realitas yang lebih tinggi dari kesadaran dirinya sendiri, yaitu kekuatan semesta yang teratur, yang membatasi hasrathasratnya dalam batasan-batasan yang stabil. Di sini kita akan memasuki lorong Phenomenology of the Spirit ${ }^{57}$-suatu kesadaran akan adanya kesadaran yang lebih tinggi, bertujuan teologis dan menyatukan. ${ }^{58}$ Pada tahap ini ontology pemahaman manusia bisa ditarik pada ujung yang lebih akhir dan bersifat ke luar. Dan pada lapis terakhir kita akan menembus lorong Phenomenology of Religion, ${ }^{59}$ yang kata Ricoeur merupakan tahapan paling tinggi eskatologis di mana pada lapisan ini ontology pemahaman manusia bisa ditarik ke atas yang melampaui masa lalu dan masa depan ke arah yang sacral. ${ }^{60}$ Yang sakral ini lebih unggul ketimbang arche maupun

53 Bukan dalam arti psikologis berupa keinginan yang menggebu, melainkan sebagai dorongan fisik primitif dari kehidupan untuk hidup. Bandingkan dengan konsep Freud tentang Id.

54 Langkah Ricoeur menggunakan psikoanalisis relatif alami, dan tidak memaksakan diri sebagaimana para psikolog transpersonalis menggunakan William James. Lihat James T. Alexander, "William James, the sick Soul and the Negative Dimensions of Counsiousness: A Partial Critique of Transpersonal Psychology," Journal of American Academy of Religion, XLVIII/2, 1980.

${ }^{55}$ Arkeologi berarti data berserakan yang tidak tersusun secara kausal. Konsep ini juga yang nantinya digunakan Foucault dalam L'Archeologie du Savoir; Ricouer, Existence and Hermeneutics..., 253.

${ }^{56}$ Ricouer, Ibid.

${ }^{57}$ Ricouer, Existence and Hermeneutics..., 254.

58 Telos sebagai sifat semesta yang purposive dalam dirinya sendiri. Tetapi kadangkala asumsi ini dianggap tidak ilmiah; Lih. pembahasan Frihjof Capra tentang teori Gaia dalam Jaring-jaring Kehidupan, Visi Baru Epistemologi dan Kehidupan, terj. Saut Pasaribu (Yogyakarta: Fajar Pustaka, 2001).

59 Fenomenologi Agama adalah cabang ilmu yang telative independent dari fenomenologi Hesserlian; Lih. Ursula King "Debat Metodologis Pasca Perang Dunia II, dalam Ahmad Norma Permata, Metodologi Studi Agama (Yogyakarta: Pustaka Pelajar, 2000), 303.

${ }^{60}$ Ricoeur merujuk pada Eliade. Namun di sisi lain, Ricoeur habis-habisan menyerang Eliade berkenaan dengan konsep tentang yang sacral yang dianggap oleh 
telos karena di luar kendali manusia. Dalam posisi ini manusia hanya dapat bersikap pasif dan menunggu panggilan dari sana. ${ }^{61}$

Dengan demikian, maka level ontologis dapat diraih dengan sempurna, tanpa kehilangan pijakan pada level methodology, yaitu melalui interpretasi. Sehingga ontology yang konkrit dan wajar bagi hermeneutika bukanlah ontology of understanding secara langsung dalam dirinya sendiri, melainkan sejauh yang dapat kita jangkau melalui interpretasi ontology. ${ }^{62}$

Dengan ketiga tahapan ini, hermeneutika tidak meletakkan posisinya di kursi metafisika dengan tenang, anggun dan aman, tanpa harus melakukan lompatan yang intuitif, melainkan tetap melalui prosedur metodologis. Setelah menyingkapkan postur hermeneutika yang berpijak di metode, meliuk di filsafat dengan logika transenden, serta menjulang menjangkau metafisika alias ontology: sekarang mari kita mengikuti lebih jauh, apa yang menjadi tema sentral dalam hermeneutika Paul Ricoeur.

\section{TUGAS-TUGAS POKOK HERMENEUTIKA}

Menurut Ricoeur, tugas utama hermeneutika adalah untuk memahami teks. Oleh karena itu, perngertian tentang teks menjadi sangat sentral dalam pemikiran hermeneutika Ricoeur. Untuk itu, kita perlu memberikan perhatian yang cermat pada poin ini.

\section{Teks dan Teori Interpretasi}

Secara mendasar, Ricoeur mengatakan bahwa teks adalah any discourse fixed by writing. ${ }^{63}$ Berpijak pada defeinisi singkat ini, pertama kali kita perlu mengetahui apa yang dimaksud dengan Ricouer dengan discourse, sebelum kita memahami tentang writing.

Dengan istilah discourse, Ricouer merujuk kepada bahasa sebagai event, yaitu bahasa yang membicarakan tentang sesuatu. Pengertian ini

Ricoeur terlalu kaku dan monoton, "Etreiten avec le philoosophe Paul Ricoeur, sur L'Eurupe, la science et Dieu."

${ }^{61}$ Mungkin menarik untuk membandingkan konsep ini dengan pandangan para mistikus yang menganggap tingkat tertinggi pengetahuan bukan pada terapan melainkan perolehan.

${ }^{62}$ Di sinilah tepatnya, poin di mana Ricoeur memadukan sekaligus mengatasi hermeneutika metodologis dan filosofis.

63 Ricoeur, "What is a text? Explanation and Understanding," dalam Hermeneutics and Human..., 145. 
diambil Ricouer dari para filsuf bahasa seperti Austin dan Beardsley ${ }^{64}$ yang membagi bahasa ke dalam dua sifat, yaitu "bahasa sebagai meaning ${ }^{65}$ dan bahasa sebagai event." Bahasa sebagai meaning adalah dimensi yang hidup dan dinamis; atau dalam ungkapan Ricouer sendiri, "bahasa selalu

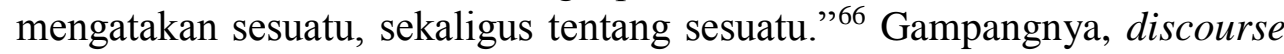
adalah bahasa ketika ia gunakan untuk berkomunikasi. Dan dalam hal ini ada dua jenis artikulasi discourse yaitu bahasa lisan dan bahasa tulis. ${ }^{67}$ Yang pertama membentuk komunikasi langsung dimana metode hermeneutik tidak terlalu diperlukan, karena ujaran yang disampaikan (speech) masih terlekat langsung kepada pembicara. Maka dari ujaran tersebut masih bisa dirujuk langsung kepada intonasi maupun gerak isyarat (gestures) dari si pembicara. ${ }^{68}$

Sedangkan teks merupakan sebuah korpus yang otonom. Ricoeur menganggap bahwa sebuah teks memiliki kemandirian, totalitas, ${ }^{69}$ yang dicirikan oleh empat hal. Pertama, dalam sebuah teks makna yang terdapat pada apa yang dikatakan (what is said) ${ }^{70}$ terlepas dari proses pengungkapannya (the act of saying), sedangkan dalam bahasa lisan kedua proses itu tidak dapat dipisahkan. ${ }^{71}$ Dalam sebuah dialog, maksud dari seorang pembicara bukan hanya ditunjukkan oleh ucapannya, melainkan juga oleh intonasi, mimik maupun gesturesnya. ${ }^{72}$ Kedua, dengan demikian makna sebuah teks juga tidak lagi terikat kepada pembicara, sebagaimana bahasa lisan. Apa yang dimaksud teks tidak lagi terkait dengan apa yang

${ }^{64}$ Ricoeur, "Text and Metaphore as ad Central Problem in Hermeneutics," 168.

${ }^{65}$ Istilah makna adalah istilah yang menarik sekaligus problematik. Bagi para pemikir positivis, mengatakan bahwa "makna berarti apa yang di belakang penampakkan;" bagi para fenomenolog ia adalah substansi atau hakikat; sedangkan bagi teolog, seperti pernah dikatakan Prof. Donna Runnals, meaning maksudnya adalah suffering.

${ }^{66}$ Ricoeur, "Metaphore and the Central Problem of Hermeneutics," 168. Dalam bidang teologi, Bultman, Ebeling dan Fuchs telah terlebih dahulu menerapkannya pada teks-teks Alkitab yang pada gilirannya melahirkan "analisa narasi” yakni bahwa teks dilihat dalam bentuk akhir, dan bahwa arti suatu teks akan menjadi jelas jika terlebih dahulu mengalami rekionstruksi bahasa yang digunakan teks.

${ }^{67}$ Ricoeur, "Metaphore and the Central...," 165-166.

${ }^{68}$ Ricoeur, "Metaphore and the Central...," 166-167.

${ }^{69}$ Ibid., 212.

${ }^{70}$ Thompson, "Editor's Introduction...," 13.

${ }^{71}$ The Act of Speaking...is constituted by a hierarchy of subordinate acts which are distributed on three level: (1) the level of locutionary or proposiotional, the act of saying; (2) the level of illocutionary act or force, that which we do in saying; (3) the level of perlucotionary act, that which we do by saying..." Ricoeur "The Model of the...," 199.

${ }^{72}$ Sangat mungkin terjadi, dengan melihat ekspresi si pembicara, apa yang ia katakan bermakna yang sebaliknya. 
awalnya dimaksudkan oleh penulisnya. ${ }^{73}$ Bukan berarti bahwa penulis tidak lagi diperlukan, meskipun Ricoeur sempat mengatakan tentang kematian penulis, ${ }^{74}$ akan tetapi maksud si penulis terhalang oleh teks yang sudah membaku. Yang tidak kalah menarik, Ricoeur menganggap bahwa penulis lebih merupakan pembaca pertama. Ketiga, karena tidak lagi terikat pada sebuah sistem dialog, maka sebuah teks tidak lagi terikat pada konteks semula (ostensive reference), ${ }^{75}$ ia tidak terikat pada konteks asli dari pembicaraan. Apa yang ditunjuk oleh teks dengan demikian, adalah dunia imajiner yang dibangun oleh teks itu sendiri dalam dirinya sendiri maupun dalam hubungan dengan teks-teks yang lain. Terakhir, dengan demikian juga tidak lagi terikat kepada audiens awal, sebagaimana bahasa lisan terikat kepada pendengarnya. Sebuah teks ditulis bukan untuk pembaca tertentu, melainkan kepada siapapun yang bisa membaca, ${ }^{76}$ dan tidak terbatas pada ruang dan waktu. Dapat dikatakan pula bahwa sebuah teks membangun hidupnya sendiri, karena sebuah teks adalah sebuah monolog.

Penjelasan lebih lanjut Ricoeur terhadap konsep teks ini juga akan menjadi revisi bagi konsep Dilthey tentang Explanation dan understanding, ${ }^{77}$ di mana Dilthey menganggap bahwa penjelasan adalah karakteristik kerja ilmu alam, yaitu untuk mengungkapkan cara kerja fenomena alami yang pasti dan tanpa intensi. Sementara pemahaman adalah cara kerja ilmu humaniora, untuk mengungkapkan perilaku manusia yang sangat kompleks, tidak kausalistik dan memiliki dimensi intensionalitas. Dan kedua metode itu bekerja secara mutual exclusive. ${ }^{78}$ Sedangkan menurut Ricoeur, kedua cara kerja metodologis tersebut tidak bisa dipisahkan secara dikotomis. Dengan menerapkan pada persoalan hubungan antara metaphor dan teks sebagai kodifikasi bahasa lisan dan bahasa tulis, Ricoeur menunjukkan bagaimana penjelasan dan pemahaman dapat diterapkan pada sisi yang berlainan. Penjelasan (explanation) adalah cara kerja yang menghubungkan metaphor kepada teks, ${ }^{79}$ yaitu pembakuan bahasa lisan kepada bahasa tulis, sementara interpretasi (interpretation)

73 "What the text says no matter more than what the author meant to say..." in "The Model of the...," 201.

${ }^{74}$ Ricoeur, "What is a...? 147.

${ }^{75}$ Ricoeur, "What is a...? 201.

${ }^{76}$ Ibid., 203.

${ }^{77}$ Ibid., 145.

${ }^{78}$ Richard Palmer mengomentari bahwa pendukung paling setia Dilthey, George Mish, sekalipun tidak mendukung dikotomi permanen ini; Lih. Palmer, Hermenutics, Interpretation Theory ..., 106.

${ }^{79}$ Ricoeur, "Metaphore and Central Problem...," 177. 
adalah cara kerja dari teks ke metaphor, yaitu transkripsi dari bahasa tulis ke bahasa lisan. ${ }^{80}$

Dengan kata lain, bahasa sebagai meaning adalah sebuah sistem tanda yang memiliki konstelasi internal, yang baku dan objektif. Di sini Ricoeur meminjam teori para strukturalis mulai dari dikotomi langue dan parole dari Ferdinand de Saussure, strukturalisme filosofis-antropologis dari Claude Levi Strauss ${ }^{81}$ hingga analisis struktural sastrawi Rolland Barthes dan A.J. Greimas. ${ }^{82}$ Bahasa memiliki hukum-hukum yang baku, yang bekerja mirip hukum alam. Ini adalah pengertian kata-kata dalam kamus atau ensiklopedi yang sudah bermakna tunggal dan baku. Dalam aspek inilah metodologi yang digunakan adalah explanation. Sedangkan bahasa sebagai event atau discourse, adalah penampang bahasa yang terikat kepada konteks. Di sini bahasa menjadi multi-interpretable, sehingga tidak mungkin ada objektivitas, apalagi pembakuan. Di sinilah, lanjut Ricoeur, tempatnya metode interpretation sebagai bentuk utama dari understanding. ${ }^{83}$

Melangkah lebih jauh lagi, Ricoeur tidak hanya ingin sekedar mendamaikan dikotomi yang diciptakan namun tidak mampu diatasi Dilthey di atas. Sampai pada tahap itu, Ricoeur hanya menempatkan explanation dan interpretation pada satu domain yaitu Geisteswissenschaften tetapi tetap saja keduanya adalah dua prosedur yang berbeda dan bekerja secara terpisah. ${ }^{85}$ Untuk ini Ricouer mengajukan prosedur kerja depth semantic ${ }^{86}$ yaitu dengan menempatkan kedua prosedur metodologis di atas dalam sebuah garis linier. Menurut Ricoeur, analisis explanation bisa digunakan sebagai tahap awal untuk mengkaji dimensi statis dari teks, sedangkan interpretation digunakan selanjutnya untuk menangkap makna kontekstual dari teks tersebut. ${ }^{87}$

Bagi Ricoeur, istilah makna kontekstual bukan lagi mengacu kepada the single meaning dari teks yang bersangkutan, karena teks itu sudah memiliki makna internal yang objektif dan tidak lagi ditopang oleh intensional psikologis dari penulisnya melainkan the multiple meaning dari

${ }^{80}$ Ricoeur, "Metaphore and Central Problem...,", 176.

${ }^{81}$ Ibid., 154.

${ }^{82}$ Ibid., 157.

${ }^{83}$ Namun dalam konteks ini Ricoeur tetap lebih memilih ungkapan interpretation sebagai bentuk derivative dari understanding.

${ }^{85}$ Ibid., 161.

${ }^{86}$ Ibid.

87 "...to explain is to bring out the structure, that is the internal relations of dependence of constitute the static of the text; to interpret is to follow the path of thought open up by the text, to place one self en route toward the orient of the text." Ibid, 161-162. 
konteks pembaca modern. Dalam sebuah pembacaan teks, seorang pembaca tidak lagi masuk ke dalam teks untuk melakukan rekonstruksi psikologis kepada pengarang, dan tidak pula menarik teks ke dalam preunderstanding-nya sendiri. Yang terjadi adalah seorang pembaca membuka dirinya di hadapan teks yang juga telah membuka diri. Makna sebuah teks tidaklah ada di balik atau di belakangnya, melainkan ada di depannya. ${ }^{88}$

\section{Sejarah Sebagai Teks}

Ricoeur memperluas konsep teks ini bukan hanya pada bahasa yang mengendap pada tulisan, melainkan juga kepada setiap tindakan manusia yang memiliki makna yaitu setiap tindakan yang disengaja untuk mencapai tujuan tertentu. Dalam hal ini dia meminjam teori Max Weber tentang sinhaft orientierties Verhalten. ${ }^{89}$ Tujuan Ricoeur dalam teori ini adalah membangun sebuah epistemology baru bagi ilmu-ilmu sosial maupun humaniora karena, berdasarkan pendalaman pada hermeneutik sebagai kajian terhadap teks, Ricoeur menganggap bahwa (1) objek dari ilmu-ilmu sosial dan humaniora memiliki karakter sebagai teks; (2) dengan demikian metodologi kajian untuk itu haruslah berupa kajian yang menyerupai kajian interpretative (Auslengung) yang ada pada hermeneutika. ${ }^{90}$

Dalam penjelasan selanjutnya, Ricoeur memaparkan bagaimana realitas sosial, atau dapat kita katakan sejarah, ${ }^{91}$ memiliki persamaan karakater dengan definisinya mengenai teks. Pertama, fixation of action, ${ }^{92}$ yaitu bahwa realitas sosial baru akan dapat dijadikan sebagi objek kajian ilmiah sejauh ia terbakukan dalam mekanisme maupun struktur seperti terbakukannya discourse dalam tulisan. Sedangkan pemahaman pada realitas sosial yang belum terbakukan, yaitu peristiwa-peristiwa yang

88 "Beyond my situation as reader, beyond the situation of the author, I offer my self to the possible mode of being-in-the-world which the text opened up the disclose to me." Ricoeur, "Metaphore and the Central Problems of Hermeneutics," 177.

${ }^{89}$ Ricoeur, "The model of text, Meaningful Action Considered as text," dalam Hermeneutics and..., 203.

${ }^{90}$ Ibid., 197.

${ }^{91}$ Pada umumnya orang menganggap sejarah sebagai kajian masa lalu jauh ( $f a r$ past); padahal realitas sosial yang kita hadapi sekarang inipun sebenarnya adalah sejarah tapi dalam jangka dekat (near past). Sehingga sebenarnya yang dapat dilakukan oleh ilmuilmu sosial-humaniora adalah sejarah; Lih. Permata, Metodologi Studi..., 21.

${ }^{92}$ Ricoeur, "The Model of...," 203. 
datang dan pergi disebut dengan knowledge without observation, yaitu pengetahuan tentang bagaimana dari realitas sosial dan bukan apa. ${ }^{93}$

Kedua, the automatiozation of action, berupa kenyataan bahwa tindakan sosial kita memiliki makna objektif ${ }^{94}$ dan bukan hanya semata tergantung kepada maksud kita belaka sebagaimana makna teks yang sudah tidak lagi tergantung kepada intensitas psikologis sang pengarang. Pada tindakan sederhana memang masih memungkinkan hubungan antara pelaku dengan perbuatannya. Namun dalam peristiwa-peristiwa sosial yang kompleks yang memiliki dampak luas, maka hubungan antara maksud dengan hasil tindakan semakin menjauh. Misalnya seorang pemimpin politik, tidaklah dinilai dari apa tujuan dari kebijakan yang ia ambil, melainkan dari hasilnya. ${ }^{95}$

Ciri ketiga dari realitas sosial yang memiliki karakter teks adalah keterlepasannya dari konteks awal tindakan atau dalam ungkapan Ricoeur sendiri adalah relevance and importance.$^{96}$ Sebagaimana sebuah teks tidak lagi harus dipahami berdasarkan konteks awalnya, demikian pula nilai penting (importance) dari sebuah tindakan sosial tidak lagi terikat baku dengan nilai pentingnya (relevance). Maksudnya, bahwa sebuah tindakan bisa bermakna lain bila dihubungkan dengan konteks yang berbeda, dan itu adalah pemahaman yang absah dilakukan. Dan inilah yang sering terjadi dalam proses hermeneutika judicial, di mana makna sebuah tindakan diperdebatkan dengan mengaitkannya kepada konteks-konteks yang berlainan. $^{97}$

Yang terakhir, penampang dari meaningful action yang menyerupai penampang sebuah teks adalah keterbukaanya kepada makna-makna baru human action sebagai "open" work yang identik dengan karakter teks yang juga equivocal. Maksudnya adalah, sebagaimana sebuah teks tidak lagi

knowledge."

93 Ibid.; dimana Ricoeur mengikti konsep E. Anscombe tentang "practical

${ }^{94}$ Cukup jelas maksudnya di sini bila kita melihat konsep Peter L. Berger tentang realitas sosial. Berger mengatakan bahwa realitas sosial terbangun dalam siklus tiga tahapan, yaitu (1) Sosialisasi, di mana sekelompok orang membentuk konvensi-konvensi sosial dalam berinteraksi, (2) konvensi tersebut kemudian menjadi sesuatu yang baku, terobjektivikasi, yang tidak lagi melekat pada individu-individu anggota masyarakat, dan (3) sosialisasi, di mana norma sosial objektif di atas diwariskan kepada generasi berikutnya, yang pada gilirannya akan mengenakan sekaligus menginovasi norma sosial ayng ada dan memulai tahapan siklus baru dengan sosialisasi; Lih. Berger, Sacred Canopy, Element of Sociological Theory of Religion (New York: Anchor Books, 1069), 4.

${ }^{95}$ Ricoeur, "The Model of ...," 206.

${ }^{96}$ Ibid., 207.

${ }^{97}$ Ibid. 
terikat kepada audiens awal dalam suatu proses dialogis bahasa lisan, demikian juga sebuah perbuatan tidak hanya dapat dinilai oleh orang-orang yang menjadi saksi mata. Sebuah tindakan menjadi terbuka untuk selamanya, bagi para penanggap baru yang datang dari ruang waktu. Yang menjadi hakim dari sebuah tindakan atau realitas sosial bukan hanya orangorang dari zaman itu, melainkan sejarah itu sendiri. ${ }^{98}$

Dengan demikian, proyek hermeneutika fenomenologis Paul Ricoeur merupakan sebuah jalan panjang dan ambisius, bukan hanya untuk menjembatani hubungan antara hermeneutika metodologi di satu sisi degan hermeneutika filosofis di sisi lain, tetapi juga membangun sebuah epistemologi baru bagi ilmu-ilmu sosial-humaniora. Epistemologi ini tidak lagi merupakan kelanjutan epistemologi tradisional, melainkan lebih pada epistemologi kritis sebagaimana yang kita jumpai dalam pemikiran hermenutika kritis baik dai Karl-Otto Apel maupun Jürgen Habermas.

\section{PENUTUP: IMPLIKASI HERMENUTIS}

Dari analisa teori interpretasi, Paul Ricoeur membawa kita untuk dapat mengantisipasi beberapa implikasi, yakni yang berkisar pada penggunaan dan pengkaburan konsep peristiwa pembicaraan dalam tradisi hermenutika romantic yang telah dibangun oleh Schleirmarcher dan Dilthey, bahwa interpretasi harus mengindentifikasi kategori pemahaman sebagai maksud mula-mula dari sudut pandang penulis teks atau si pembicara. Dalam hal ini Ricoeur mengajak untuk mempertanyakan asumsi hermeneutika ini dari sudut pandang anatomi bahasa, bahwa tanpa adanya suatu penyelidikan khusus terhadap tulisan (teks), suatu teori analisa bahasa belum dapat menjadi suatu teori teks. Namun bila suatu teks dapat diakomodir oleh teori analisa bahasa, maka kondisi inskripsi bahasa berada dalam persyaratan yang memungkinkan terjadinya suatu wacana dalam pengaruh teks. Dalam artian bahwa apa yang terjadi dengan teks adalah manifestasi sepenuhnya pembicaraan yang hidup, yakni pemilahan makna dari peristiwa, yakni otonomi teks tetap muncul dalam aturan dialektika peristiwa dan makna teks.

Di sinilah Ricoeur menawarkan sebuah proyek yang menarik dalam rangkuman ilmu teologi dan filsafat sebagai suatu pendekatan bagi kajiankajian hermeneutika yang berguna bagi suatu analisis kritis dalam dunia interpretasi.

${ }^{98}$ Ibid., 208; Ricoeur mengutip ungkapan Hegel Wltgenschichte ist Weltgerict. 